\title{
PERANCANGAN DAN PEMBUATAN PROTOTYPE SHANK PROSTHESES KAKI BAGIAN BAWAH LUTUT
}

\author{
Agung Prakoso \\ Program Studi Aeronautika \\ STT Adisutjipto \\ Jl. Janti Blok R Lanud Adisutjipto Yogyakarta \\ prakosoagung84@gmail.com
}

\begin{abstract}
The existence of feet as the part of the human body is very important to support the daily activities which is to support the body and to walk. The lost of the under knee part (amputation) is the dominant case of the total cases of amputation in Indonesia. So that we need a tool to restore the balance of the human body to be able to do our daily activity. The tool is called prostheses. The design and manufacture of prototypeshank prostheses under knee is intended for persons who have $162 \mathrm{~cm}$ height and $57 \mathrm{Kg}$ of average weight. Prostheses are aimed to the persons who only lost one limb below the knee. In this design, the length of the shank can be set according to the length of leg amputated and is intended to persons who are still experiencing high growth (teenager). The material is stainless steel 316L. The shank has a length $200-300 \mathrm{~mm}$, width $67 \mathrm{~mm}$ and $2 \mathrm{~mm}$ thick.
\end{abstract}

Keywords: Prostheses, shank

\begin{abstract}
Abstrak
Keberadaan kaki sebagai anggota gerak tubuh manusia sangatlah penting untuk menunjang aktivitas sehari-hari, di mana kaki berfungsi untuk menopang tubuh dan berjalan. Ketiadaan kaki bagian bawah lutut (amputasi) merupakan kasus yang dominan dari total kasus ketiadaan anggota gerak tubuh manusia di Indonesia. Sehingga diperlukan suatu alat untuk mengembalikan keseimbangan tubuh manusia untuk dapat beraktivitas sehari-hari. Alat pengganti anggota gerak tubuh yang hilang adalah prostheses. Perancangan dan pembuatan prototype shank prostheses kaki bagian bawah lutut ini ditujukan untuk individu dengan tinggi $162 \mathrm{~cm}$ dan dengan berat tubuh rata-rata $57 \mathrm{Kg}$. Prostheses ini ditujukan kepada individu yang hanya kehilangan satu anggota gerak bawah lutut. Pada rancangan ini, ukuran panjang shank dapat diatur sesuai dengan panjang kaki yang diamputasi dan ditujukan untuk individu yang masih mengalami pertumbuhan tinggi (remaja). Bahan yang dipakai adalah stainless steel 316L. Shank ini memiliki panjang 200-300 mm, lebar $67 \mathrm{~mm}$ dan tebal batang $2 \mathrm{~mm}$.
\end{abstract}

Kata kunci: Prostheses, shank

\section{Pengantar}

Tubuh manusia normal mempunyai sepasang kaki yang merupakan bagian tubuh manusia yang berfungsi sebagai alat gerak bawah. Selain sebagai alat gerak, kaki juga berfungsi sebagai alat penyeimbang tubuh serta sebagai alat aktivitas sehari-hari. Ketiadaan atau defisiensi kaki merupakan masalah bagi manusia, karena fungsi yang seharusnya dijalankan oleh organ tubuh tersebut tidak ada dan tubuh manusia menjadi tidak seimbang. 
Pada tahun 2012 sejumlah 400 orang penyandang kaki buatan akibat kecelakaan dan bencana mendapatkan kaki buatan Sugeng Siswoyudono yang terkenal melalui acara Kick Andy dan dilaksanakan melalui kerjasama dengan Polda Jawa Tengah (Setiadi, 2012). Kaki buatan Sugeng juga pernah diberikan kepada korban bom Palu di Sulawesi Tengah dan korban tsunami Banda Aceh melalui Kick Andy Foundation (Priambodo, 2010).

\section{Latar Belakang Masalah}

Prostheses adalah suatu pengganti untuk bagian tubuh yang hilang, meski definisi tersebut berhubungan dengan tidak adanya telinga, mata, gigi atau bagian tubuh lain akan tetapi yang menjadi pembahasan disini adalah bagian tubuh yang berfungsi sebagai alat gerak (Sinaki,1993). Terdapat dua penyebab atas ketiadaan alat gerak tubuh, yaitu akibat amputasi dan akibat defisiensi bawaan. Pada kasus amputasi, alat gerak semula ada, namun karena beberapa alasan tertentu misalnya kecelakaan atau penyakit, alat gerak tersebut harus dihilangkan. Sedangkan pada kasus defisiensi bawaan, tubuh seseorang tersebut memang tidak terdapat alat gerak tertentu sejak lahir.

Ketiadaan alat gerak bawah atau kaki secara garis besar dibagi menjadi dua yaitu ketiadaan kaki atas lutut (above-knee) dan ketiadaan kaki bawah lutut (below-knee). Pada ketiadaan kaki, bagian penghubung antara foot, ankle dan soket adalah shank yang berfungsi untuk memindahkan dan membagi beban dari soket ke bagian foot. Terdapat dua jenis shank, yaitu exoskeletal dan endoskeletal (Campbell, 2002). Keuntungan endoskeletal shank yaitu lebih modern, lebih mampu menopang beban tubuh, lebih kuat. Kekurangan shank ini yaitu lebih mahal, pembuatan lebih sulit dan rumit, pelapisan bagian luar kurang berdaya tahan

\section{Metodologi Penelitian}

Permasalahan yang dibahas dalam bab ini adalah merancang dan membuat prototype shank prostheses bagian bawah lutut. Langkah-langkah perancangan dan pembuatan yang digunakan dapat dilihat pada gambar 1 .

\section{A. Tahap Identifikasi Awal Perancangan dan Pembuatan}

Alasan pemakaian prostheses oleh orang yang kehilangan anggota gerak tubuhnya antara lain adalah sebagai berikut:

a. Menggantikan peran dan fungsi organ tubuh yang tidak ada untuk menjalankan aktivitas hidup sehari-hari.

b. Mengurangi perasaan rendah diri akibat frustasi kehilangan bagian tubuh.

c. Meningkatkan penyesuaian diri dan menumbuhkan rasa percaya diri dalam berperilaku sosial.

d. Menginginkan suatu alat yang dapat lebih menjamin keamanan dan kemandirian individu. 
Gambar 1. Metodologi Perancangan

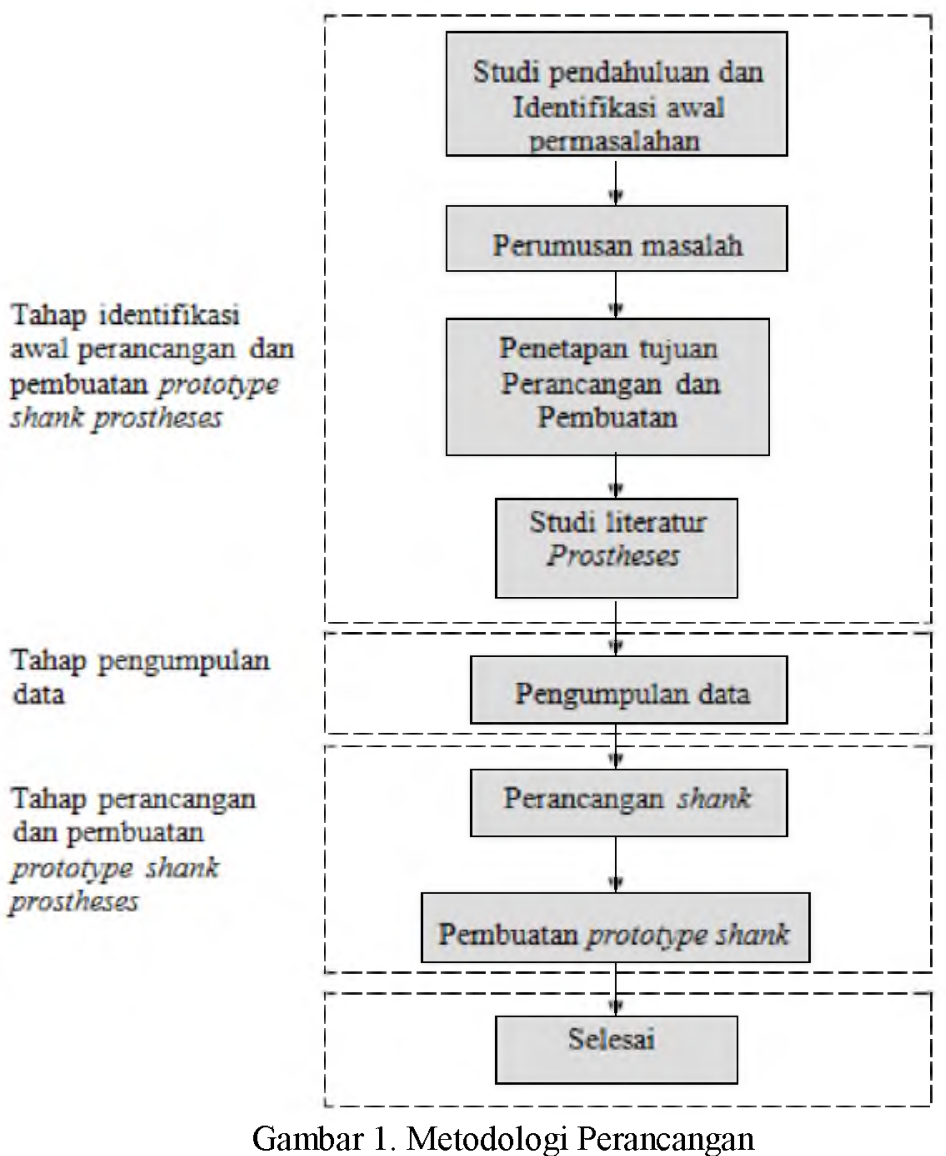

\section{B. Tahap Pengumpulan Data}

Data yang diperoleh berasal dari internet, buku-buku prosthetic, pusat rehabilitai Yakum, dan dari rumah sakit Orthopedi Profesor Dr. Soeharso Solo. Data tersebut berupa rancangan-rancangan prostheses dari mulai yang masih sederhana sampai perkembangannya menjadi lebih maju.

\section{Tahap Perancangan dan Pembuatan Shank Prostheses}

Prostheses yang dirancang merupakan pengembangan dari rancangan-rancangan yang sudah ada. Hal itu sesuai dengan tujuan perancangan dan pembuatan prostheses tersebut. Prostheses yang akan dirancang adalah bagian shanknya saja.

Biomekanis kaki artinya aksi gaya yang terjadi pada kaki manusia. Kaki sebagai anggota gerak bawah berfungsi untuk berjalan dan menopang tubuh. Siklus berjalan manusia dimulai saat kaki kontak dengan lantai dan berakhir saat kaki yang sama menyentuh lantai.

Terdapat dua fase saat kaki berjalan yaitu fase berdiri dan fase berayun. Fase berdiri (stance phase) merupakan bagian siklus di mana tungkai acuan berkontak dengan lantai, dimulai saat tumit menyentuh lantai (heel strike), bergerak sampai semua kaki menyentuh lantai dan tumit terangkat (toe-off). Fase berayun (swing phase) merupakan bagian siklus di mana tungkai acuan tidak menyentuh lantai. Fase ini dimulai dengan tidak tersentuhnya kaki ke lantai dan berakhir saat tumit menempel ke lantai (heel strike). 


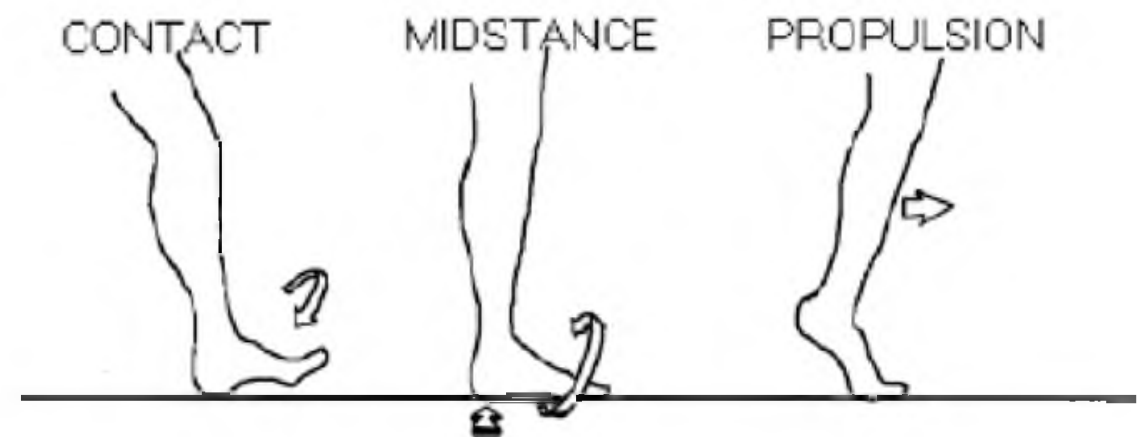

Gambar 2. Fase berdiri (stance phase) (Campbell.2002)

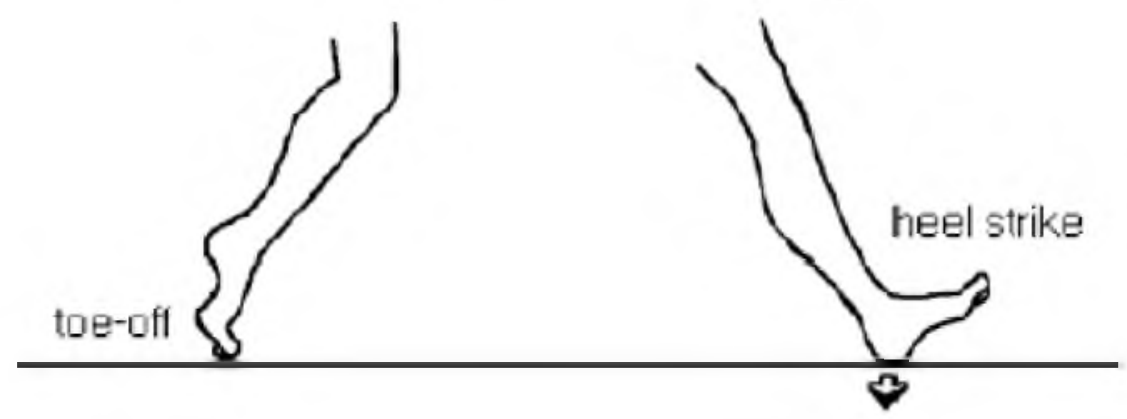

Gambar 3. Fase berayun (swing phase) (Campbell,2002)

Selama proses berjalan seluruh bobot tubuh ditumpu pada satu kaki (kaki kiri dalam gambar 3), beban tertinggi yaitu pada saat berjalan dengan tumpuan satu kaki. Dengan demikian perlu dicari beban tertinggi pada mekanisme berjalan. Gaya yang bekerja pada kaki ketika membawa berat tubuh keseluruhan ditunjukkan dalam gambar 5. Misal selama berdiri pada satu kaki, $F_{M}$ adalah magnitudo dari gaya resultan yang dikeluarkan oleh otot-otot abduktor pinggul, $\mathrm{F}_{\mathrm{J}}$ adalah magnitudo gaya reaksi sendi yang diaplikasikan oleh panggul pada tulang paha, $\mathrm{W}_{1}$ adalah berat kaki, $\mathrm{W}$ adalah berat total tubuh yang diaplikasikan sebagai suatu gaya normal oleh tanah pada kaki. Sudut antara batas usaha kekuatan otot resultan dan horisontal ditunjukkan oleh $\theta$.

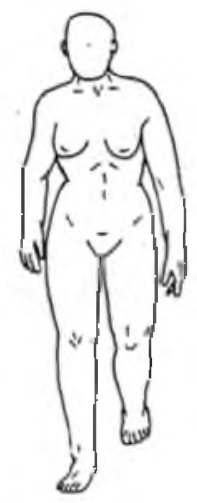

Gambar 4. Berdiri dengan satu kaki (Azkaya dan Nordin,1991) 


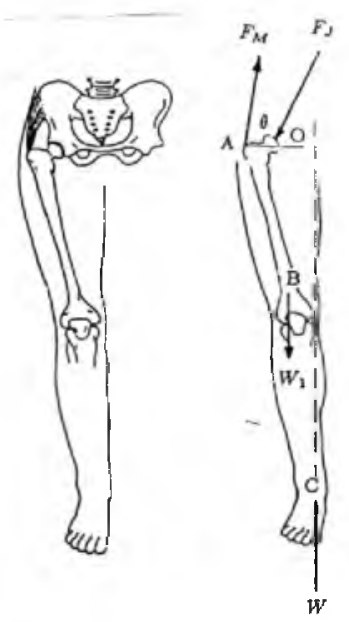

Gambar 5. Gaya-gaya yang bekerja pada kaki kanan yang menopang berat keseluruhan tubuh (Azkaya dan Nordin,1991)

Suatu model mekanika kaki, komponen-komponen persegi dari kekuatan yang bekerja, dan parameter-parameter yang dibutuhkan untuk menyelesaikan soal ditunjukkan dalam gambar 6 . O adalah suatu titik di sepanjang sumbu yang terjadi seketika itu juga pada rotasi sendi pinggul, $\mathrm{B}$ adalah pusat gravitasi pada kaki, dan $\mathrm{C}$ adalah di mana kekuatan reaksi tanah diaplikasikan pada kaki. Jarak antara $\mathrm{A}$ dan $\mathrm{O}, \mathrm{B}$, dan $\mathrm{C}$ ditentukan secara berurutan menjadi $a, b$, dan $c$. $\alpha$ adalah sudut pencondongan leher tulang paha pada horisontal, dan $\beta$ adalah sudut yang dibuat sumbu panjang pada tangkai tulang paha dengan horisontal. Oleh karenanya, $\alpha+\beta$ kira-kira sama dengan total sudut leher ke tangkai dari tulang paha (Azkaya dan Nordin, 1991).

Untuk menentukan gaya yang dikeluarkan oleh otot-otot abduktor pinggul dan gaya reaksi sendi pada pinggul untuk mendukung kaki dan pinggul pada posisi yang ditunjukkan yaitu:

Penyelesaian Menggunakan diagram bebas tubuh pada kaki.

Untuk menyelesaikan soal tersebut, digunakan diagram bebas tubuh pada kaki kanan yang menopang berat keseluruhan orang tersebut. Dalam gambar 6a, gaya otot dan reaksi sendi ditunjukkan dalam kaitan komponen-komponennya pada arah $x$ dan $y$. Gaya otot resultan memiliki suatu garis kerja yang membuat suatu sudut $\theta$ dengan horisontal. Oleh karenanya:

$$
\begin{aligned}
& \mathrm{F}_{\mathrm{Mx}}=\mathrm{F}_{\mathrm{M}} \cos \theta \\
& \mathrm{F}_{\mathrm{My}}=\mathrm{F}_{\mathrm{M}} \sin \theta
\end{aligned}
$$

Karena sudut $\theta$ ditetapkan (ditentukan sebagai suatu hitungan jumlah), satu-satunya yang tidak diketahui pada gaya otot adalah magnitudonya, $F_{M}$. Untuk gaya reaksi sendi, tak ada satupun dari magnitudo maupun arah yang diketahui. Dengan mengacu pada sumbu di mana sendi pinggul terletak pada $\mathrm{O}, a_{x}$ pada gambar $6 \mathrm{~b}$ adalah lengan momen pada komponen vertikal $F_{M y}$ gaya otot, dan $a_{y}$ adalah lengan momen $F_{M x}$. Serupa dengan itu, $\quad\left(b_{x}-a_{x}\right)$ adalah lengan momen untuk $W_{1}$ dan $\left(c_{x}-a_{x}\right)$ adalah lengan momen untuk gaya $W$ yang diaplikasikan oleh tanah pada kaki.

Dari hitungan soal:

$$
\begin{aligned}
& \mathrm{a}_{\mathrm{x}}=\mathrm{a} \cos \alpha \\
& \mathrm{a}_{\mathrm{y}}=\mathrm{a} \sin \alpha \\
& \mathrm{b}_{\mathrm{x}}=\mathrm{b} \cos \beta \\
& \mathrm{c}_{\mathrm{x}}=\mathrm{c} \cos \beta
\end{aligned}
$$


Sekarang ketika komponen vertikal dan horisontal semua gaya tercakup, dan lenganlengan momennya dengan mengacu pada $\mathrm{O}$ ditentukan, kondisi untuk ekuilibrium rotasi kaki di sekitar $O$ dapat digunakan untuk menentukan magnitudo gaya otot resultan yang diaplikasikan pada A. Dengan menganggap bahwa momen-momen berdasarkan putaran jarum jam adalah positif:

(a)

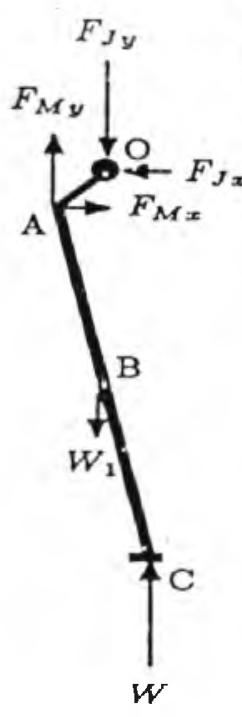

(b)

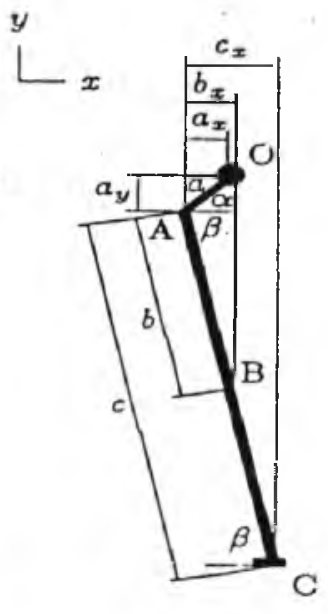

Gambar 6(a). Diagram bebas tubuh pada kaki, (b). Parameter-parameter hitungan. (Azkaya dan Nordin,1991)

Keterangan:

$\mathrm{F}_{\mathrm{M}}=$ resultan gaya otot abduktor

$\mathrm{F}_{\mathrm{J}}=$ gaya reaksi sendi

$\mathrm{W}_{1}=$ berat kaki

$\mathrm{W}=$ berat total tubuh

$\theta=$ sudut $\mathbf{F}_{\mathrm{M}}$ dengan horisontal

$\alpha=$ sudut pencondongan leher tulang paha pada horisontal

$\beta=$ sudut tangkai tulang paha dengan horisontal

$a_{x}=$ lengan momen $\mathrm{F}_{\mathrm{My}}$

$a_{y}=$ lengan momen $\mathrm{F}_{\mathrm{Mx}}$

$\left(b_{x}-a_{x}\right)=$ lengan momen untuk $W_{1}$

$\left(c_{\mathrm{x}}-\mathrm{a}_{\mathrm{x}}\right)=$ lengan momen untuk gaya $\mathrm{W}$

$\sum M_{O}=0: \quad a_{x} F_{M y}-a_{y} F_{M x}-\left(c_{x}-a_{x}\right) W$

$+\left(b_{x}-a_{x}\right) W_{i}=0$

Dengan mensubstitusikan persamaan (1) sampai (4) kedalam persamaan diatas:

$(\mathrm{a} \cos \alpha)\left(\mathrm{F}_{M} \sin \theta\right)-(\mathrm{a} \sin \alpha)\left(\mathrm{F}_{M} \cos \theta\right)$

$-(\mathrm{c} \cos \beta-\mathrm{a} \cos \alpha) \mathrm{W}+(\mathrm{b} \cos \beta-\mathrm{a} \cos \alpha) \mathrm{W}_{1}=0$

Penyelesaian persamaan untuk gaya otot:

$\mathrm{F}_{\mathrm{M}}=\frac{\left(c W-b W_{1}\right) \cos \beta-a\left(W-W_{1}\right) \cos \alpha}{a(\cos \alpha \sin \theta-\sin \alpha \cos \theta)}$ 
Penyebut dari persamaan (5) dapat disederhanakan menjadi a $\sin (\theta-\alpha)$. Untuk menentukan komponen-komponen pada gaya reaksi sendi, dapat menggunakan kondisi ekuilibrium vertikal dan horisontal kaki:

$$
\begin{array}{ll}
\sum F_{x}=0: & \mathrm{F}_{\mathrm{JX}}=\mathrm{F}_{\mathrm{Mx}}=\mathrm{F}_{\mathrm{M}} \cos \theta \\
\sum F_{y}=0: & \mathrm{F}_{\mathrm{Jy}}=\mathrm{F}_{\mathrm{My}}+\mathrm{W}-\mathrm{W}_{1} \\
& \mathrm{~F}_{\mathrm{Jy}}=\mathrm{F}_{\mathrm{M}} \sin \theta+\mathrm{W}-\mathrm{W}_{1}
\end{array}
$$

Oleh karenanya, gaya resultan yang bekerja pada sendi pinggul adalah:

$$
\mathrm{F}_{\mathrm{J}}=\sqrt{\left(F_{d x}\right)^{2}+\left(F_{J y}\right)^{2}}
$$

Anggap bahwa parameter-parameter hitungan dari soal dan berat kaki dihitung dalam istilah-istilah: tinggi orang $h$ dan berat total $\mathrm{W}$ sebagai berikut: $a=0,05 h, b=0,219 h$, $c=0,52 h, \quad \alpha=45^{\circ}, \beta=80^{\circ}, \theta=70^{\circ}$, dan $\mathrm{W}_{1}=0,1665 \mathrm{~W}$. Gaya reaksi sendi membuat suatu sudut $\varnothing=\tan ^{-1}\left(\mathrm{~F}_{\mathrm{Jy}} / \mathrm{F}_{\mathrm{Jx}}\right)=74.8^{\circ}$ (Azkaya dan Nordin, 1991).

\section{Hasil dan Pembahasan}

Perancangan dan hasil dari bagian-bagian shank prostheses dalam penelitian ini adalah sebagai berikut:

\subsection{Bagian yang disambungkan dengan soket}
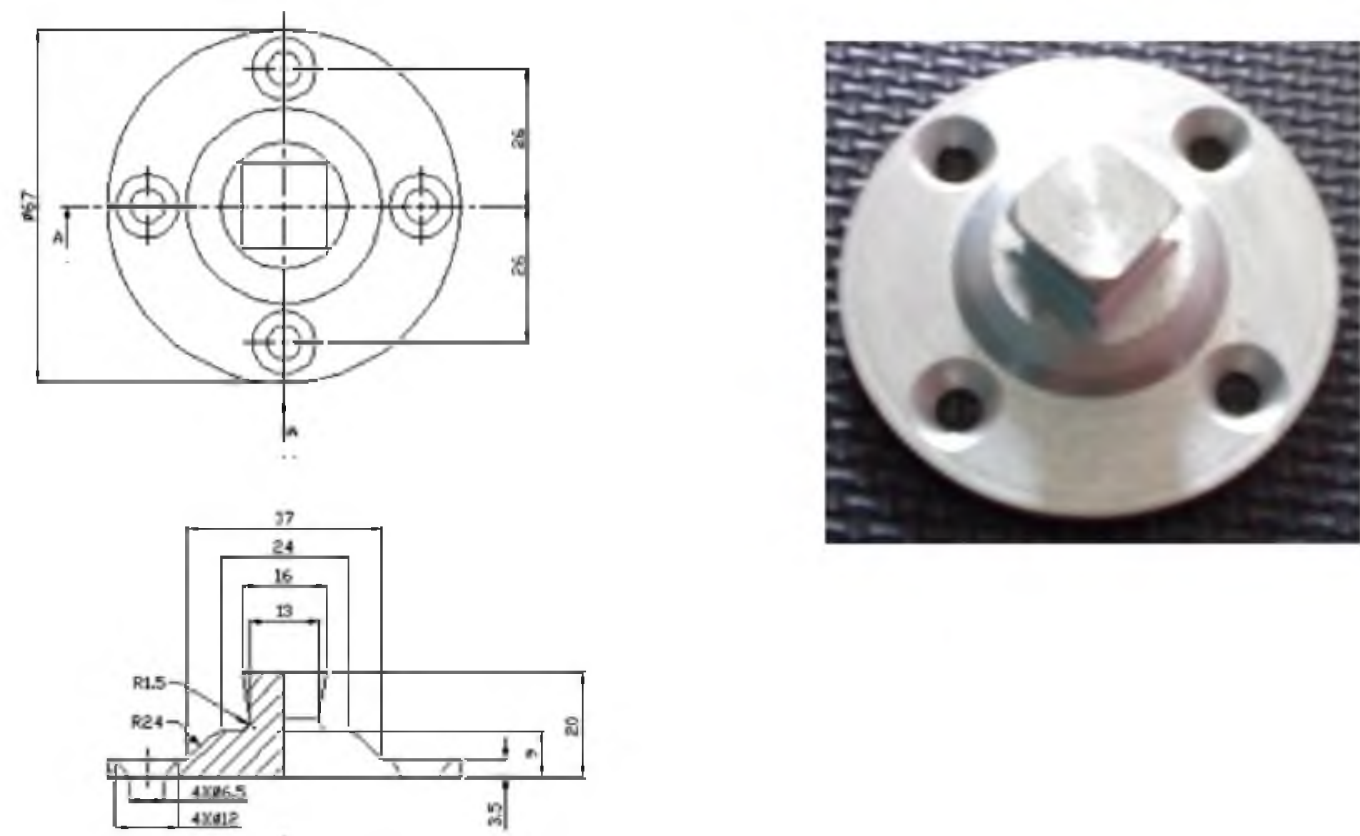

SECTION A-A

Gambar 7. Penghubung soket (satuan mm) 


\subsection{Bagian angkle yaitu penghubung dengan foot}
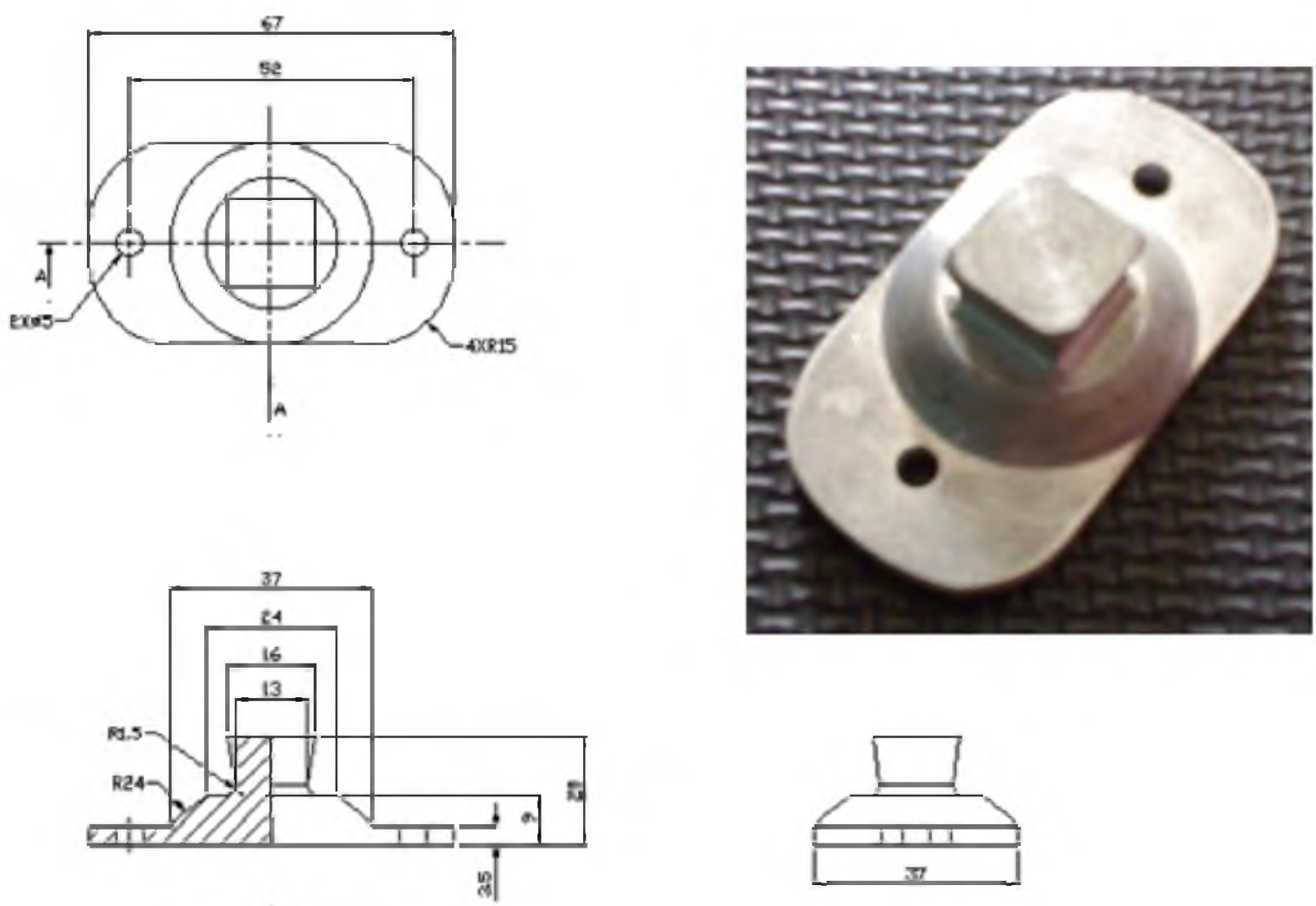

SECTION A-A

Gambar 8. Angkle penghubung foot (satuan mm)

\subsection{Bagian batang}
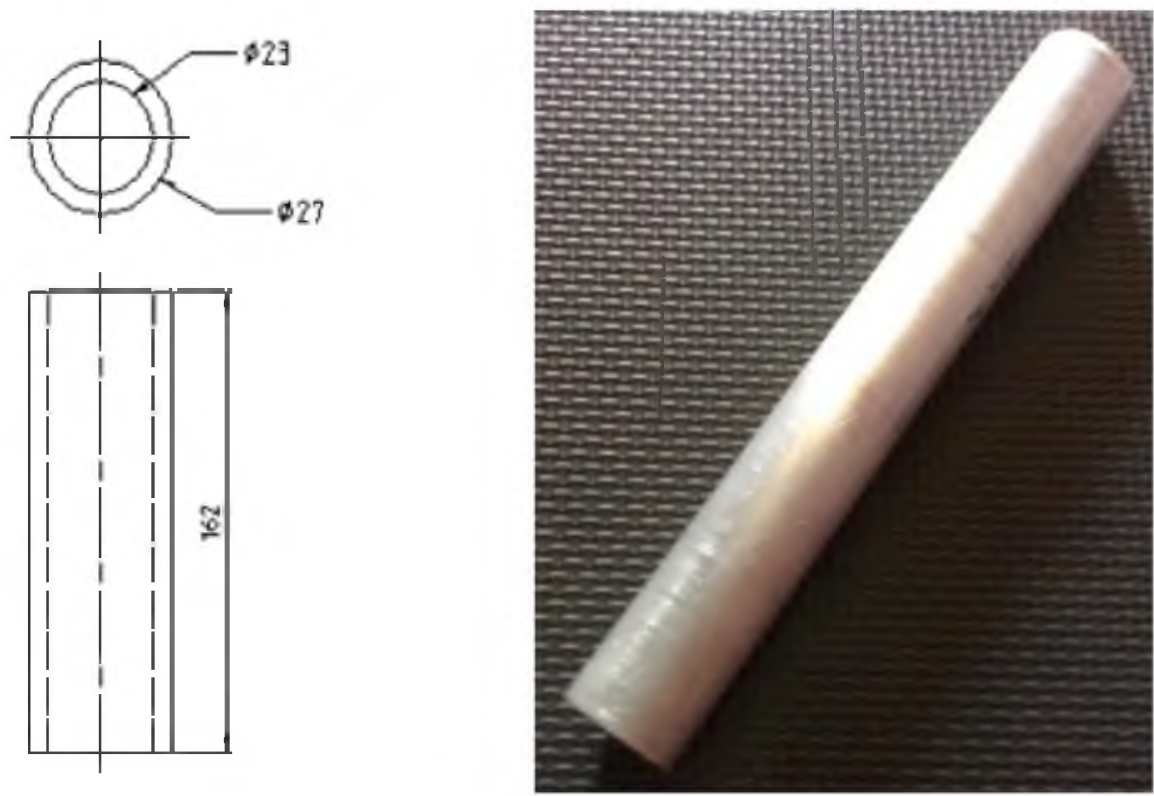

Gambar 9. Batang (satuan mm) 


\subsection{Bagian penghubung batang dengan angkle}
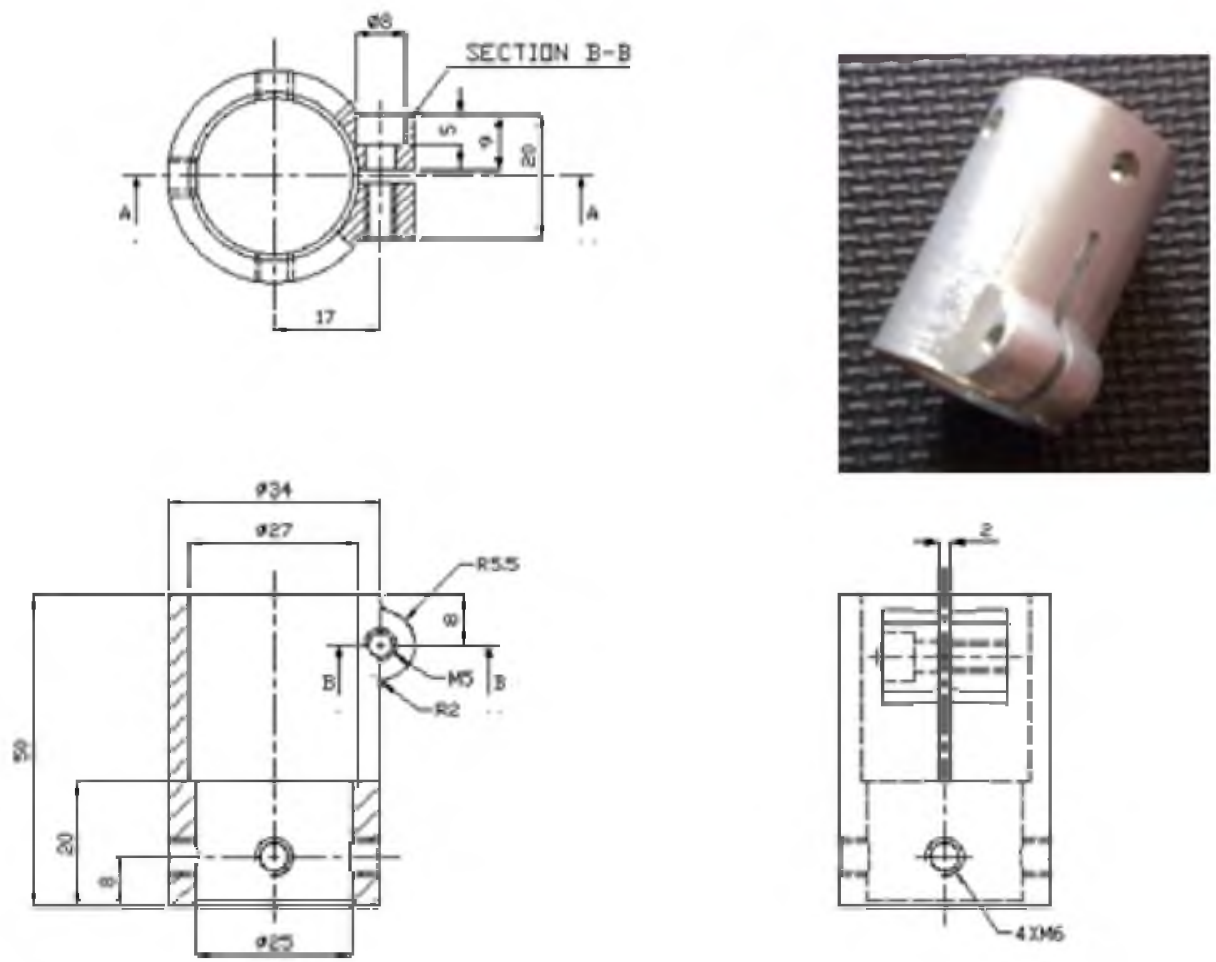

SECTION A-A

Gambar 10. Penghubung batang dengan angkle (satuan mm)

\subsection{Bagian penghubung soket dengan batang}
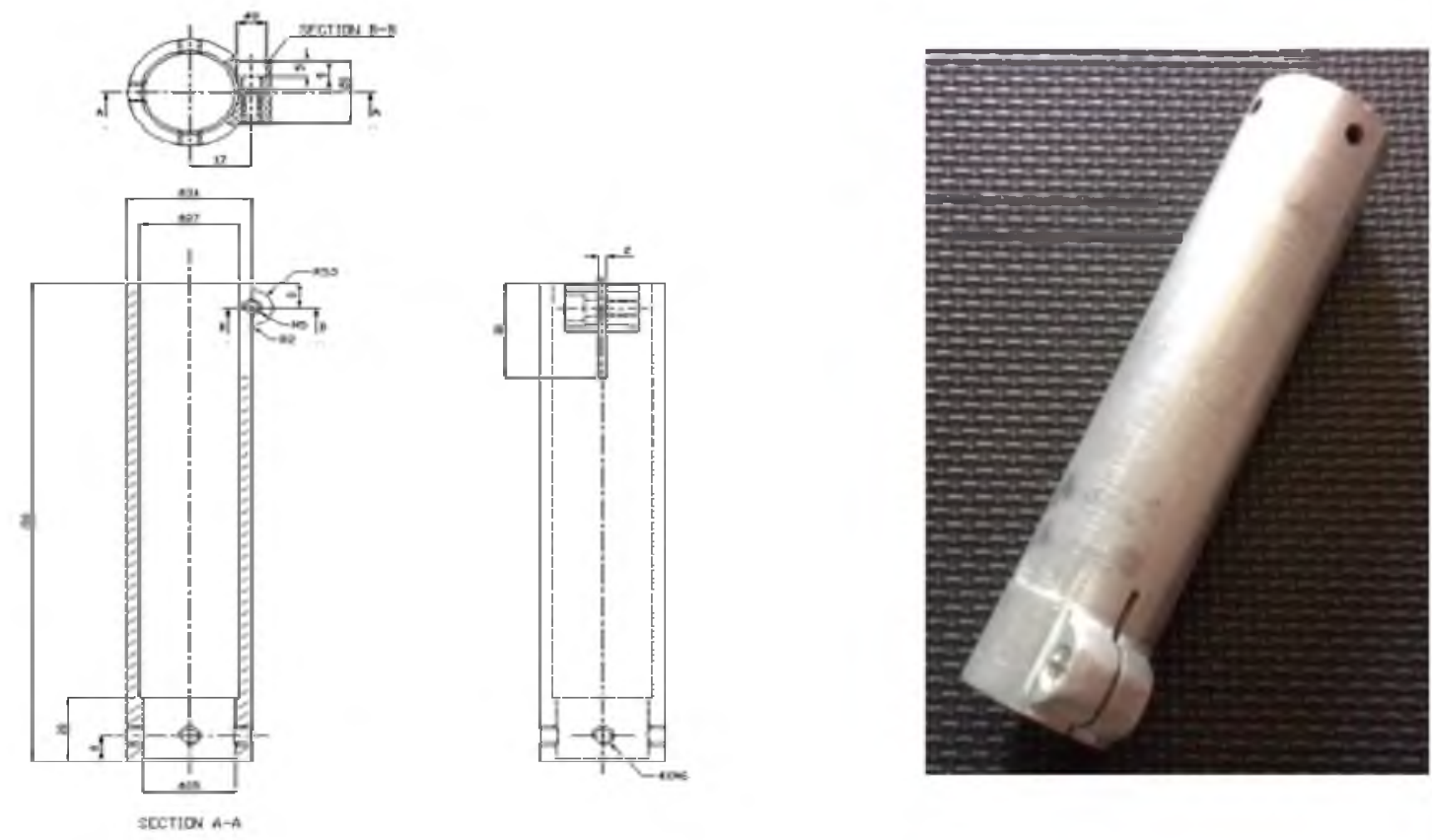

Gambar 11. Penghubung soket dengan batang (satuan mm) 
Bahan yang dipilih dalan perancangan shank prostheses adalah stainless steel. Stainless steel yang biasa digunakan aplikasi prostheses adalah stainless steel tipe 316L. Bahan ini sering digunakan karena memiliki sifat-sifat kuat $\left(\sigma_{\mathrm{u}}=48,5 \mathrm{~kg} / \mathrm{mm}^{2}\right)$, beratnya $7,9 \mathrm{~g} / \mathrm{cm}^{3}$, tahan terhadap korosi, dan nonmagnetic.

A. Menghitung beban maksimum ( $\left.\mathrm{P}_{\text {maks }}\right)$

Untuk melakukan perhitungan pada batang diperlukan suatu asumsi yang nantinya akan digunakan sebagai dasar perhitungan. Adapun asumsi tersebut adalah tinggi tubuh (h) $162 \mathrm{~cm}$ sehingga didapat berat tubuh :

$$
\begin{aligned}
\mathrm{W} & =\mathrm{h}-110( \pm 10 / 100 \times \text { selisih }) \\
& =162-110( \pm 0,1 \times 52) \\
& =57,2 \mathrm{~kg} \\
& \approx 57 \mathrm{~kg}
\end{aligned}
$$

Dalam hal ini dicari perhitungan pada saat beban tertinggi yaitu pada saat berjalan dengan tumpuan satu kaki (Azkaya dan Nordin, 1991). Beban maksimum pada kaki dihitung dari gaya reaksi sendi $\left(\mathrm{F}_{\mathrm{J}}\right)$. Asumsi bahwa parameter-parameter hitungan dan berat kaki dihitung dalam istilah-istilah: tinggi orang $(h)$ dan berat total (W) sebagai berikut: $a=0,05 h$, $b=0,219 h, c=0,52 h, \alpha=45^{\circ}, \beta=80^{\circ}, \theta=70^{\circ}$, dan $\mathrm{W}_{1}=0,1665 \mathrm{~W}$. Gaya reaksi sendi membuat suatu sudut $\varnothing=\tan ^{-1}\left(\mathrm{~F}_{\mathrm{Jy}} / \mathrm{F}_{\mathrm{Jx}}\right)=74.8^{\circ}$. Kita ambil tinggi manusia $\mathrm{h}(162 \mathrm{~cm})$ dan berat $\mathrm{W}(57 \mathrm{~kg})$, maka nilai $\mathrm{a}=8,1 \mathrm{~cm}, \mathrm{~b}=35,478 \mathrm{~cm}, \mathrm{c}=84,24 \mathrm{~cm}, \mathrm{~W}_{1}=9,5 \mathrm{~kg}$.

Untuk gaya otot :

$$
\begin{aligned}
& \mathrm{F}_{\mathrm{M}}=\frac{\left(c W-b W_{1}\right) \cos \beta-a\left(W-W_{1}\right) \cos \alpha}{a(\cos \alpha \sin \theta-\sin \alpha \cos \theta)} \\
& \mathrm{F}_{\mathrm{M}}=\frac{(84,24.57-35,478.9,5) \cos 80-8,1(57-9,5) \cos 45}{8,1(\cos 45 \sin 70-\sin 45 \cos 70)} \\
& \mathrm{F}_{\mathrm{M}}=147 \mathrm{~kg}
\end{aligned}
$$

Gaya resultan yang bekerja pada sendi pinggul :

$$
\begin{aligned}
\mathrm{F}_{\mathrm{J}} & =\sqrt{\left(F_{J x}\right)^{2}+\left(F_{J y}\right)^{2}} \\
\mathrm{~F}_{\mathrm{JX}} & =\mathrm{F}_{\mathrm{Mx}}=\mathrm{F}_{\mathrm{M} \cos \theta} \\
\mathrm{F}_{\mathrm{JX}} & =145,55 \mathrm{~kg} \cos 70 \\
& =49,78 \mathrm{~kg} \\
\mathrm{~F}_{\mathrm{Jy}} & =\mathrm{F}_{\mathrm{M}} \sin \theta+\mathrm{W}-\mathrm{W}_{1} \\
\mathrm{~F}_{\mathrm{Jy}} & =147 \mathrm{~kg} \sin 70+(57-9,5) \mathrm{kg} \\
& =185,63 \mathrm{~kg} \\
\mathrm{~F}_{\mathrm{J}} & =\sqrt{(50,28)^{2}+(185,63)^{2}} \\
\mathrm{~F}_{\mathrm{J}} & =192,32 \mathrm{~kg}
\end{aligned}
$$

B. Ultimate strength $\left(\sigma_{\mathrm{u}}\right)$ stainless steel $=485 \mathrm{Mpa}=485 \mathrm{~N} / \mathrm{mm}^{2}=48,5 \mathrm{~kg} / \mathrm{mm}^{2}$

C. Faktor keamanan (n)

Dari tabel suggested values for factor of safety untuk jenis pembebanan statis adalah 3-4. diambil faktor keamanan 4 . 
D. Tegangan tekan yang diijinkan (Suyitno,1995)

$\sigma_{\mathrm{ijin}}=\frac{\text { ultimate } \text { strength }}{\text { faktor..keamanan }}=12,125 \mathrm{~kg} / \mathrm{mm}^{2}$

E. Diameter luar batang (D)

Pada rancangan batang, batang yang digunakan adalah batang berongga dengan diameter luar $(D)=27 \mathrm{~mm}$.

F. Luas penampang (A)

Misalkan garis tengah lingkaran dalam adalah $\mathrm{x}$ mm, maka luas penampang kolom:

$$
\begin{aligned}
& \mathrm{A}=\frac{\pi}{4}\left(\mathrm{D}^{2}-\mathrm{x}^{2}\right) \\
& \mathrm{A}=\frac{\pi}{4}\left(27^{2}-\mathrm{x}^{2}\right)
\end{aligned}
$$

Apabila batang tersebut diharapkan mampu menahan beban, tegangan yang terjadi harus lebih kecil atau sama dengan tegangan ijinnya :

$$
\begin{aligned}
& \sigma \leq \sigma_{\mathrm{ijin}} \\
& \frac{P \text { maks }}{\mathrm{A}} \leq 12,125 \\
& \mathrm{~A} \geq 15,86 \mathrm{~mm}^{2}
\end{aligned}
$$

G. Tebal dinding minimum $\left(t_{\min }\right)$

Dari persamaan (9) dan (10) didapat :

$\frac{\pi}{4}\left(27^{2}-x^{2}\right) \geq 15,86$

$\mathrm{x} \geq 26,62 \mathrm{~mm}$

jadi, tebal dinding minimum batang tersebut :

$\mathrm{t}_{\min }=\frac{D-x}{2}=0,2 \mathrm{~mm}$

H. Tegangan tekan yang terjadi $\left(\sigma_{c}\right)$

Luas penampang batang $(\mathrm{A})=\mathrm{A}_{1}-\mathrm{A}_{2}$.

Pada perancangan, tebal $(\mathrm{t})$ dinding yang digunakan adalah $2 \mathrm{~mm}$.

Dengan $A_{1}=$ luas penampang bagian luar

$$
\begin{aligned}
& =\pi / 4 \mathrm{D}^{2} \\
& =572,265 \mathrm{~mm}^{2}
\end{aligned}
$$

$$
\begin{aligned}
\mathrm{A}_{2} & =\text { luas penampang bagian dalam } \\
& =415,265 \mathrm{~mm}^{2}
\end{aligned}
$$

Jadi $\mathrm{A}=\mathrm{A}_{1}-\mathrm{A}_{2}=157 \mathrm{~mm}^{2}$ 
Tegangan tekan yang terjadi pada batang :

$$
\begin{aligned}
\sigma_{\mathrm{c}} & =\frac{P \text { maks }}{\mathrm{A}}<\sigma_{\mathrm{ijin}} \\
& =\frac{192,32}{157}<12,125 \mathrm{~kg} / \mathrm{mm}^{2} \\
& =1,225 \mathrm{~kg} / \mathrm{mm}^{2}<12,125 \mathrm{~kg} / \mathrm{mm}^{2}
\end{aligned}
$$

I. Mencari Beban tekuk ijin ( $\left.\mathrm{P}_{\text {cr ijin }}\right)$

Dari Anthropometry, panjang body segment dari kaki bagian bawah lutut yang diamputasi tanpa foot adalah:

$$
\mathrm{L}_{\mathrm{kaki}}=(0,285 \mathrm{H})-(0,039 \mathrm{H})=(0,285.162)-(0,039.162)=39,852 \mathrm{~cm}
$$

Misalkan sisa panjang kaki yang diamputasi dari lutut ke bawah adalah 9,852 cm, maka bagian kaki yang diamputasi adalah:

$\mathrm{L}_{\text {ampt }}=39,852 \mathrm{~cm}-9,852 \mathrm{~cm}=30 \mathrm{~cm}=300 \mathrm{~mm}$

Dengan mengacu bahwa kondisi batang adalah jepit-jepit, maka gaya tekuk dan beban tekuk ijin dapat dicari :

Modulus elastisitas stainless steel $=200 \mathrm{GPa}=20.000 \mathrm{~kg} / \mathrm{mm}^{2}$

Tebal rancangan $2 \mathrm{~mm}$ jadi diameter dalam $(\mathrm{d})=23 \mathrm{~mm}$

Faktor keamanan $(\mathrm{n})=4$

Momen inersia batang berongga:

$$
\mathrm{I}=\frac{\pi}{64}\left(\mathrm{D}^{4}-\mathrm{d}^{4}\right)=12344,125 \mathrm{~mm}^{4}
$$

Panjang efektif untuk jepit-jepit :

$$
\begin{aligned}
\mathrm{L} & =182 \mathrm{~mm} \\
\mathrm{Le} & =\frac{L}{2} \\
& =\frac{182}{2} \\
& =91 \mathrm{~mm}
\end{aligned}
$$

Gaya tekuk pada batang :

$$
\mathrm{P}_{\mathrm{cr}}=\frac{\pi^{2} E . I}{L_{e}{ }^{2}}=293.945,5 \mathrm{~kg}
$$

Beban tekuk ijin :

$$
\mathrm{P}_{\text {crijin }}=\mathrm{Pcr} / \mathrm{n}=73.486,4 \mathrm{~kg}
$$

Jadi, beban tekan maksimum yang paling aman adalah $73.486,4 \mathrm{~kg}$

Beban yang dipakai hanya $192,32 \mathrm{~kg}<73.486,4 \mathrm{~kg}$ jadi tidak terjadi buckling. 


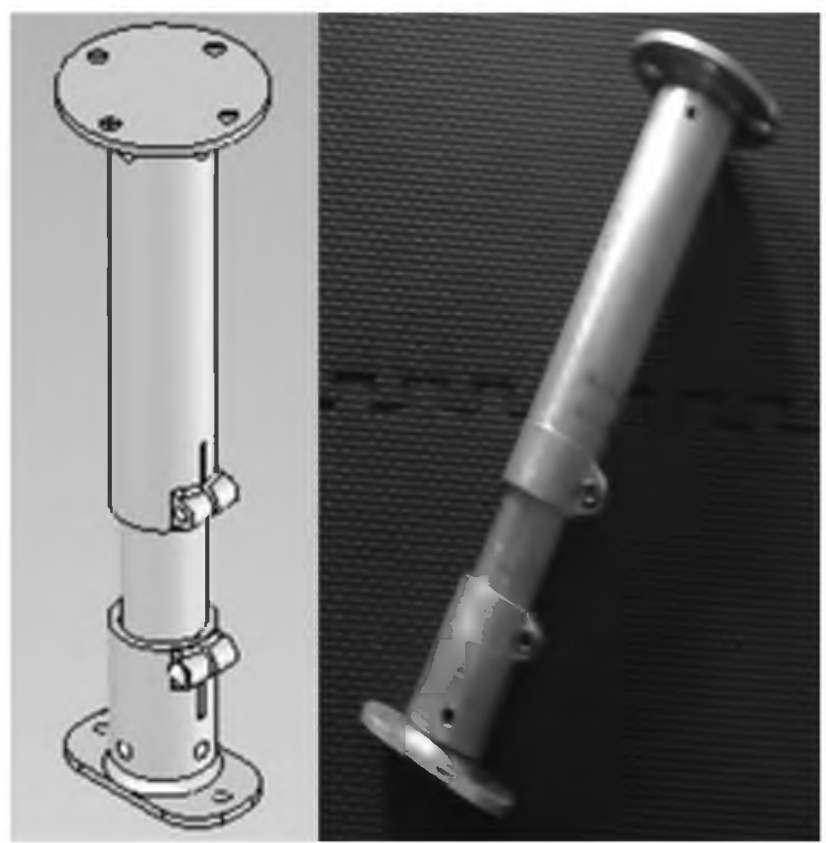

Gambar 12. Hasil Rancangan Shank Prostheses

Setelah shank selesai kemudian di-assembly dengan disambung dengan soket, foam dan foot.

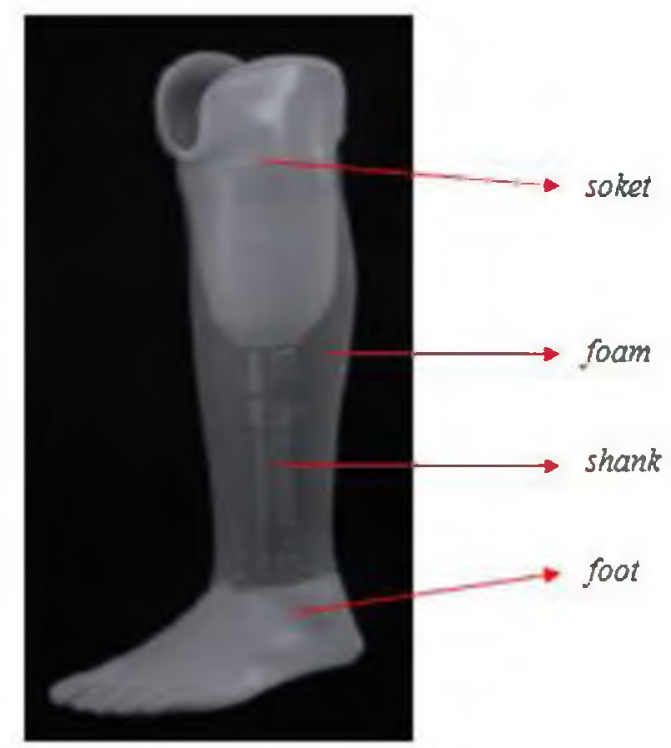

Gambar 13. Assemblyshank dengan soket, foam dan foot 


\section{Kesimpulan}

1. Perancangan shank prostheses dengan dimensi panjang $300 \mathrm{~mm}$, lebar $67 \mathrm{~mm}$ dan tebal batang $2 \mathrm{~mm}$ dengan bahan stainless steel 316L mampu menahan beban maksimum tubuh yaitu pada individu dengan tinggi $162 \mathrm{~cm}$ dengan berat $57 \mathrm{~kg}$.

2. Shank prostheses ini dapat diatur panjang pendeknya sesuai dengan panjang kaki yang diamputasi.

3. Dimensi utama shank prostheses, Panjang $=200-300 \mathrm{~mm}$, Lebar $=67 \mathrm{~mm}$, Tebal batang $=2 \mathrm{~mm}$

\section{Daftar Pustaka}

Azkaya, N., Nordin A., 1991, Fundamentals of Biomechanics Equilibrium, Motion, and Deformation, $2^{\text {nd }}$ Edition, Springer.

Campbell, J.A., 2002, Material Selection in an Above Knee Prosthetic Leg, Journal of Engineering Material, Vol.7, Hal. 14.

Priyambodo, R.H, (2010), Korban Bom Palu Terima Bantuan Kaki Palsu, online: http://www.antaranews.com/berita/229673.

Setiadi, S., (2012), Kick Andy: Bank Mandiri Bantu 400 Kaki Palsu, online: http://www.solopos.com/2012/08/03. 